\title{
Organizational reputation risk management as a component of the dynamic capabilities management process ${ }^{\prime}$
}

Professor Kazimierz Krzakiewicz Poznań University of Economics Professor Szymon Cyfert Poznań University of Economics

\section{Introduction}

Dynamic capabilities constitute an important theoretical construct useful for understanding the phenomenon of competition. First and foremost, dynamic capabilities are different from operational capabilities in that they stress the processes of change management. In the literature on the subject it is most often pointed out that dynamic capabilities constitute a company's potential to integrate, create and reconfigure internal and external competencies in order to ensure compatibility with the everchanging conditions of the environment (Teece 2008). K. Eisenhardt and J. Martin see dynamic capabilities as inter-organizational processes of integrating, reconfiguring and obtaining resources or disposing of them in order to ensure consistency with the changes on the market or to generate such changes (Eisenhard, Martin 2010).

1 The project was financed with the funds from the National Science Centre awarded based on the decision number DEC-2013/11 / B / HS4 / 00697 
Intangible assets, such as reputation, brand value, strategic position, alliances, knowledge, human capital, play an increasingly important role in shaping the market value of an organization. At the same time, in the literature it is emphasized that the attribute of intangibility translates into an increased risk of destruction or impairment of assets. Thus, the research problem associated with the analysis of organizational reputation risk management as a component of the dynamic capabilities management process should be considered important from the point of view of management science.

This article sets out to discuss the idea of organizational reputation risk management as a component of the dynamic capabilities management process. The article starts with a description of the concept of dynamic capabilities and the concept of risk, and then proceeds to relationship between dynamic capabilities and organizational reputation risk management.

\section{The concept of dynamic capabilities}

There are three issues critical for the concept of dynamic capabilities: the degree of capability "dynamics", the role of the anticipatory actions of managers and the impact of the environment on the shaping of dynamic capabilities. Three approaches to defining the aforesaid issues and viewing dynamic capabilities are highlighted in the literature on the subject.

In the first approach, based on the premises of evolutionary theory and the concept of strategy founded on classical microeconomic logic, it is assumed that capability dynamics has a limited impact on a company's success and that the role of managers in this process is also limited. According to the assumptions of the theory of population ecology and the theory of evolution, in the course of their development, organizations make habits and create sets of routine behaviors which not only constitute the main cause of organizational inertia but also disorganize the process of shaping new behavior models. Moreover, the process of capability renewal is hampered by: the historical trajectory of a company's development, complementary assets (the development of new technologies or new markets can reduce their value) and "windows of opportunity" (if an organization fails to adjust its potential to the emerging technologies and markets, doing so at a later time may be difficult or, in extreme cases, impossible). It should be noted that the historical trajectory of development and complementary assets constitute important elements of the concept of dynamic capabilities, which embeds them in methodological grounds other than the traditionally understood ones.

1

KAZIMIERZ KRZAKIEWICZ

SZYMON CYFERT 
In the second approach, managers are believed to play the key role in creating dynamic capabilities. At the same time, it is assumed that there is a link between the pace and nature of changes and the turbulence and dynamics of the environment. In a "moderately turbulent" environment changes occur relatively often, are predictable, and are linear, as a result of which dynamic capabilities may be regarded in terms of routine behaviors. In a "turbulent" environment, capabilities take the form of simple, experimental and dynamic processes. In other words, the mechanism of learning, influenced by the dynamics and changeability of the environment, lies at the heart of the evolution of dynamic capabilities. Therefore, in the literature on the subject it is highlighted that the concept of dynamic capabilities helps to explain the phenomena occurring in the sectors characterized by fast technological change. Based on this assumption, $\mathrm{H}$. Mintzberg criticized the school of strategic planning, pointing out that "analysis" (i.e. a methodology of strategic planning) should be reserved for the process of managing organizations in a relatively stable environment, while "synthesis" (i.e. strategic management) should be used in a dynamic and turbulent environment (Mintzberg 1999).

Having analyzed the phenomenon of competition in a dynamic environment, K. Eisenhardt and J. Martin noted that problems with supporting dynamic capabilities result from improvisation in the management process, since such capabilities are not "memorized", which means that external threats to the durability of competitive advantage are complemented by internal threats (Eisenhardt, Martin, 2010). Basing their theory on the foregoing observation and assuming that different kinds of dynamic capabilities may converge (the phenomenon of "the best management practices"), K. Eisenhardt and J. Martin present a mechanism for building competitive advantage different from the one described in the main trend of the concept of dynamic capabilities (Teece 2008). Assuming that it is impossible for a company to secure a sustainable advantage in dynamic sectors, K. Eisenhardt and J. Martin remark that from the point of view of gaining competitive advantage, the value of dynamic capabilities results from the possibility to configure resources, which means that it is not directly connected with the capabilities themselves. Therefore, dynamic capabilities are an indispensable but insufficient condition for gaining competitive advantage. Moreover, K. Eisenhardt and J. Martin maintain that the concept of dynamic capabilities should not be presented in terms of a separate paradigm of the theory of strategic management.

In the third approach, referring to the original premises of the concept of dynamic capabilities (Teece 2008), it is assumed that the effectiveness of the use 
of dynamic capabilities depends on the level of development of an organization's meta-capabilities, being a conglomerate of two interrelated factors: the ability to identify new business opportunities and to use them effectively. As opposed to the approaches described above, D. Teese's proposal is based on a combination of the idea of "asymmetrical" advantage and organizational adaptation to change, and on the synthesis of the concepts of organizational learning, leadership, entrepreneurship and economic theories of the company. The fundamental assumption of D. Teese's theory is that ensuring the effectiveness of the processes of organizational learning is a critical condition for gaining and maintaining competitive advantage (Zollo, Winter 2002), which means that the degree of utilization of dynamic capabilities is not determined by the dynamics and turbulence of the environment. However, the foregoing assumption does not mean that organizations should be in a permanent state of change, which, in the long run, would result in internal chaos. What is more, not all responses of an organization to innovation and change should be seen as dynamic capabilities (Winter 2003).

Moreover, it is emphasized that competitive advantages can result only from the processes of shaping external and internal competencies of an organization within the scope of creating new combinations of assets, which are difficult to replicate (Teece 2008). Such dynamic capabilities cannot be bought on the market - they can only be shaped as new capabilities or configured from the existing ones. Managers and their entrepreneurial behaviors are believed to play a crucial role in the process of shaping dynamic capabilities. D. J. Teece classifies four organizational capabilities as dynamic capabilities:

- the shaping of effective innovation and change management processes,

- intuition and vision indispensable for creating new business models,

- the shaping of the mechanisms for making effective investment decisions,

- effective management of transactions.

In order to build and maintain dynamic capabilities, the mechanisms enabling a real-time response to the changes in the environment must be incorporated into the management system of an organization. Reputational risk management is one of the mechanisms supporting the dynamic capabilities management process in a meaningful way.

\section{The essence of the risk management process}

An analysis of risk management processes in contemporary organizations reveals an excessive appreciation of procedure codification activities, while 
attaching less importance to projects related to the implementation of risk management mechanisms and tools. As a consequence of this state of affairs, risk management processes, instead of enabling a quick response to changes in the environment, lead to the petrifaction of the existing solutions and domination of the bureaucratic approach.

One of the reasons for this is the excessive focus of the persons responsible for ensuring the effectiveness of the risk management process on two issues: avoidance of threats and attempts to ensure that the decisions made are consistent with formal regulations and standards, which leads to the strong involvement of the participants and resources allocated to the risk management process in projects related to financial control and compliance with formal procedures.

Seeing risk as a threat, managers usually pay attention to the potential negative consequences associated with it, which include financial loss, loss of reputation, environmental pollution, failure to meet the planned parameters of the products, as well as stress and accidents at work (Attitudes of UK Managers to Risk and Uncertainty 2001). They forget, however, that what one organization perspectives as a major threat, another may see as a key factor of success, and they also ignore the role of emotions and subjective factors in the decisionmaking processes. The foregoing considerations allow the observation that the dominant approach to risk management, due to its failure to take into account both the negative and positive aspects of risk and not paying due attention to the impact of subjective and behavioral factors, appears to be overly simplistic and not very effective from the perspective of building stable grounds for competitive advantage.

The shift of the emphasis in the risk management process from the passive approach, aimed at counteracting threats, to the proactive approach, based on the use of opportunities, is closer to the original meaning of the concept of "risk", which comes from the Italian word "risicore" meaning "to venture" something. To risk and to strive for something new are corresponding concepts, so if someone risks in order to improve the reputation of an organization, such action in itself is positive.

To recapitulate the foregoing and in an attempt to formulate the key guidelines for the effective implementation of the risk management process, four assumptions should be made:

- it is not just the negative but also the positive aspects of risk that are significant,

- the personnel and organizational aspects of risk are as important as the analysis of risk management processes and the construction of risk management solutions, 
- the greater the willingness to take risks, the greater the prospective benefits, and the more likely the occurrence of crisis phenomena.

- the willingness to take risks is determined by the acceptance of risk, which is a component of organizational culture.

\section{Reputation and reputational risk}

The structure of assets in contemporary organizations is subject to the phenomenon of "virtualization", which consists in the concentration of the essential parts of values or business potential in intangible resources, among which reputations occupies a significant place. A good reputation, along with trust in the brand, stimulates the loyalty of contractors, translates into permanent relationships, ensures the effectiveness of knowledge management processes, and allows the acquisition of employees with desired skills. The value of reputation may also be affected by: the ways of developing business relationships by a given organization, the scope and quality of communication, the opinion about the organization as a workplace or business partner (Głuszek 2013).

Reputation is formed over a long period and depends on the behavior of the members of the organization and the quality of products and services. In the literature it is pointed out that reputation has a positive impact on the market position and financial standing of a company, since companies enjoying a good reputation achieve above-average financial results and are able to maintain them over longer periods (Dąbrowski 2012). At the same time, it is emphasized that there is a link between intangible assets and reputational risk, and that intangible assets translate into specific forms of reputational risk (see table 1.).

Table 1. Intangible assets and reputational risk

\begin{tabular}{l|l}
\hline $\begin{array}{l}\text { Intangible } \\
\text { assets }\end{array}$ & Associated with reputational risk. \\
\hline $\begin{array}{l}\text { Reputation } \\
\text { and trust }\end{array}$ & $\begin{array}{l}\text { Reputation and management form the basis of stakeholders' expectations as } \\
\text { regards corporate behavior. }\end{array}$ \\
\hline $\begin{array}{l}\text { Mutual } \\
\text { relationships }\end{array}$ & $\begin{array}{l}\text { Mutual relationships enable the identification and assessment of reputational risk, } \\
\text { and have an impact on the management of a given company. }\end{array}$ \\
\hline $\begin{array}{l}\text { Culture and } \\
\text { values }\end{array}$ & $\begin{array}{l}\text { Reputational risk is managed not because it is advised by external consultants, } \\
\text { and not because it is expected by the supervisory board. Reputational risk } \\
\text { is directly related to organizational behavior - both individual (values) and } \\
\text { corporate (culture). }\end{array}$ \\
\hline
\end{tabular}

11

KAZIMIERZ KRZAKIEWICZ

SZYMON CYFERT 


\begin{tabular}{l|l}
$\begin{array}{l}\text { Leadership } \\
\text { and commu- } \\
\text { nication }\end{array}$ & $\begin{array}{l}\text { Reputational risk - these are the powers of the supervisory board, but its } \\
\text { understanding depends on communication systems, which should provide real } \\
\text { and comprehensible information. }\end{array}$ \\
\hline Knowledge & $\begin{array}{l}\text { Reliable information on the attitudes of employees, customers and shareholders } \\
\text { towards the organization plays a major role in understanding reputational } \\
\text { risk. Knowledge is formed both as a result of the use of a variety of resources } \\
\text { and methods, and the process of market research aimed at acquiring reliable } \\
\text { information. }\end{array}$ \\
\hline
\end{tabular}

Source: own study on the basis of Zaman 2004

According to the assumptions of the classic approach to defining reputational risk, it includes events starting from wrong management decisions to scandals, which, in the long run, can have a negative impact on the trust of customers, suppliers, employees, shareholders or authorities, and the sources of reputational risk may include 1) inadequate interactions between a given organization and the entities in its environment, 2) failures associated with the production of goods and services, and 3) problems with respecting formal and legal processes. Referring to the content of the above definition, strongly emphasizing the issues of trust, it should be noted that it overlooks:

- ethics and values,

- management processes and leadership,

- organizational behavior and interpersonal relationships,

- the social context,

i.e. the variables that constitute the components of organizational identity, described with the use of the construct of organizational reputation.

\section{Organizational reputation risk management}

In the studies dedicated to the problem of reputation, the concept of organizational reputation is relatively rarely exposed. Fombrum (2010) assumes that organizational reputation is a collective idea of the past activities and results of an organization, reflecting its ability to offer products and services important for satisfying the needs of various stakeholders. Dowling (2011) emphasized that organizational reputation constitutes a system of company vales accepted by stakeholders, securing trust in it, having an impact on the environment, and the support that an organization having a good reputation in the eyes of stakeholders can get. 
In an attempt to define the notion of organizational reputation, one should specify the entity from the perspective of which reputation is developed. The assumption that organizational reputation is derived from the assessment of an organization's potential made by internal and external observers, makes it necessary to analyze organizational reputation from the perspective of the organization's relationships with key stakeholders (see table 2.)

Table 2. Organizational reputation from the perspective of key stakeholders' expectations

\begin{tabular}{l|l|l}
\hline Stakeholders & Expectations & Reputational image \\
\hline Employees & $\begin{array}{l}\text { To earn trust } \\
\text { To show support } \\
\text { To inspire pride }\end{array}$ & Trustworthy \\
\hline Investors & $\begin{array}{l}\text { To demonstrate effectiveness } \\
\text { To support stability } \\
\text { To maintain the prospects of growth }\end{array}$ & Reliable \\
\hline Customers & $\begin{array}{l}\text { To improve the quality of production } \\
\text { To secure customer service }\end{array}$ & Unfailing \\
\hline Society & $\begin{array}{l}\text { To work for the society } \\
\text { To care for the natural environment }\end{array}$ & Responsible \\
\hline
\end{tabular}

Source: own study on the basis of Fombrun 2010

Since organizational reputation affects a given company's ability to integrate, create and reconfigure internal and external resources ensuring a high level of adaptation to the changing environmental conditions, it should be considered an important component of an organization's dynamic capabilities. At the same time, as a result of the assumption that organizational reputation describes the way in which key stakeholders perceive the behavior of a given organization and the actions of its participants, when attempting to analyze organizational reputation from the perspective of the concept of dynamic capabilities one should refer to: 1) the role of key stakeholders, 2) potential contradictions in perception (which indicate a high probability of risk), and 3) organizational behavior (see table 3 and figure 1). 
Table 3. Dynamic capabilities of an organization from the perspective of the business rules affecting reputation

\begin{tabular}{l|l}
\hline $\begin{array}{l}\text { Organizational behavior } \\
\text { and reputation }\end{array}$ & $\begin{array}{l}\text { The reputation of a business is built on the mutual relationships with } \\
\text { stakeholders. The basic elements of these relationships consist of a } \\
\text { variety of benefits that an organization can offer to its stakeholders and } \\
\text { of how stakeholders assess the current activities of the company. }\end{array}$ \\
\hline $\begin{array}{l}\text { The trust and } \\
\text { responsibilities of } \\
\text { stakeholders }\end{array}$ & $\begin{array}{l}\text { These factors, forming the basis of effective mutual relationships, include } \\
\text { the ideas about the reliability and solidity of a given business and the } \\
\text { ability to process in a turbulent and unpredictable environment. They } \\
\text { also indicate the willingness of stakeholders to support the relationships } \\
\text { with a given organization. }\end{array}$ \\
\hline $\begin{array}{l}\text { Long-term good } \\
\text { relationships }\end{array}$ & $\begin{array}{l}\text { They secure the possibility of expanding access to the resources used } \\
\text { by a given organization, cooperating with stakeholders, developing } \\
\text { cooperation and introducing innovation in the search for constructive } \\
\text { solutions to problems. }\end{array}$ \\
\hline
\end{tabular}

Source: own work

Experience in the area of cooperation of stakeholders with a given organization

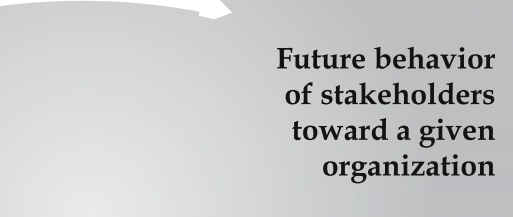

Perception of a given organization by stakeholders

Future behavior of stakeholders organization

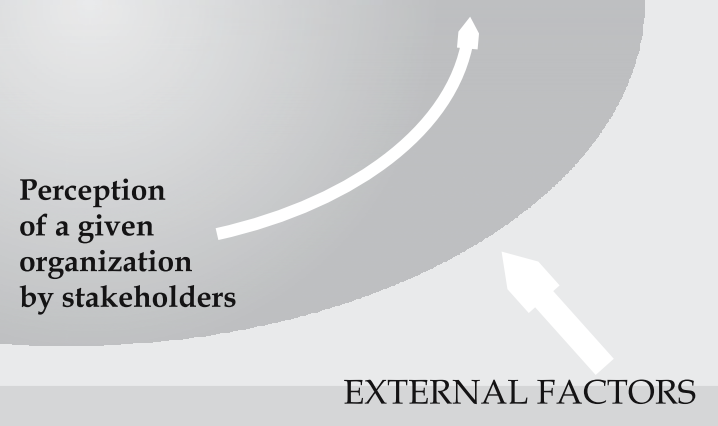

Figure 1. Relationships shaping reputation as a component of an organization's dynamic capabilities

Source: own work

Organizational reputation risk management as a component of the dynamic capabilities 
The factors affecting organizational reputation, derived from both rational decisions and subjective feelings, are associated with the expectations of stakeholders and are determined by:

- the means of communication within an organization,

- the dominant system of values and organizational culture,

- the overall results of the operations of an organization,

- relationships with business partners,

- the principles of operation of an organization.

In an attempt to define the catalog of variables having a positive impact on organizational reputation one should also refer to the factors which destroy it. As demonstrated by the studies conducted in the Department of Organization and Management Theory of the Poznań University of Economics, the factors damaging to organizational reputation include:

- low efficiency of activities, directly related to the manufacturing process of products and services,

- unsatisfactory level of achievement of organizational goals or of forming relationships with various stakeholders, and, in particular, with employees,

- contradictions in the system of values or breech of values, crises in relationships with the social environment.

Organizational reputation refers to the predictability and repeatability of the activities implemented by and in a given organization, and depends on the likelihood of meeting stakeholder's expectations by the organization. So defined organizational reputation depends on (Zaman 2004): 1) previous organizational behavior related to the meeting of an organization's obligations and honesty towards stakeholders, 2) the behavior and expectations of stakeholders. Having trust in an organization, in situations in which the results of operations or the integrity of the organization are criticized, stakeholders will be guided by the principle of giving "the benefit of doubt" to the other party.

Organizations should shape their reputation using the so-called three "Ps" - "Performance", "Policy" and "Perception" (results of activities, policies and perceptions) and three "Ts" - "Truth", "Transparency" and "Trust" (true information, transparency and trust). The use of these factors should be based on the principle: "listen, learn and participate" rather than "decide, inform and defend" (Olsen 2002). Thus, organizational reputation should be treated as an important component of an organization's assets and dynamic capabilities, and not as the classic approach would have it - as an element of responsibility. 
Organizational reputation risk should be considered as a separate category of risk, taking into account its relationship with other risk components. In spite of the foregoing directive, organizational reputation risk is most often considered in the context of "loss" or "crisis". The main reason for this is the lack of reputation risk analysis when taking reputation into consideration as a trait of the mutual relationships between stakeholders and a given organization, and recognizing risk as a phenomenon having an internal growth potential. In this context, it is worth emphasizing the failure to take into account the importance of emotional factors in the shaping of the expectations of key stakeholders and building relationships with them.

Both in management theory and practice it is increasingly more often emphasized that the increase in the level of uncertainty and turbulence in the environment should be regarded not so much as a random element of the competitive landscape but rather as a permanent phenomenon. As a result, traditional risk planning and measurement processes, the results of which constitute risk management procedures and forecasts, are transformed in order to enable the prediction of unknown factors, especially in areas relating to intangible risk. Therefore, despite the underrating of the importance of organizational reputation risk referred to above, it can be observed that more

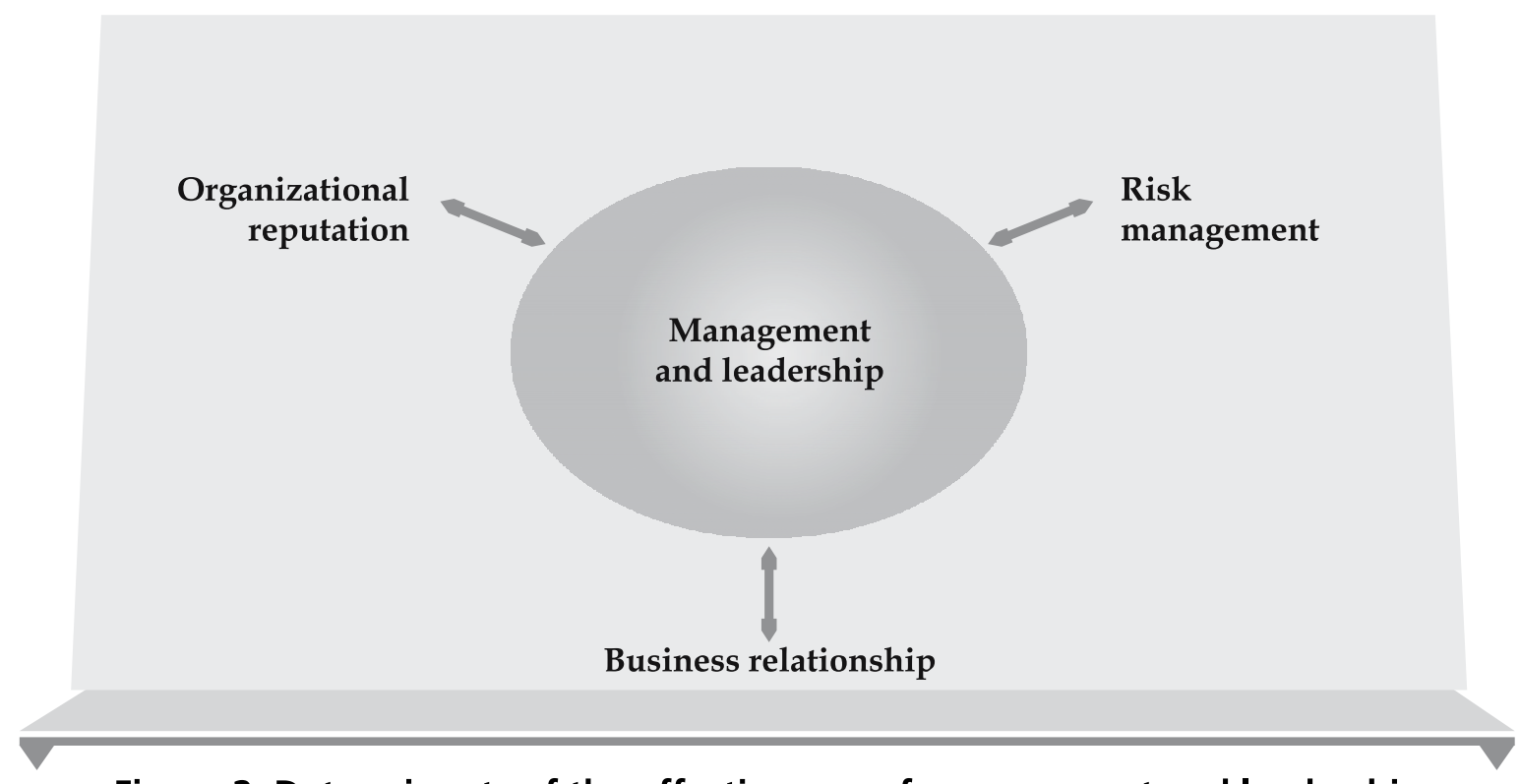

Figure 2. Determinants of the effectiveness of management and leadership

Source: own work

Organizational reputation risk management as a component of the dynamic capabilities 
and more managers are treating organizational reputation risk as an important determinant of the effectiveness of the management process (Carey Turnbull 2000), focusing on objective conditions, supporting desired organizational behavior making it possible to ensure the efficiency of actions, and taking into account the long-term and short-term consequences of the actions (see fig. 2).

\section{Summary}

Organizational reputation risk management as a component of the dynamic capabilities management process

Intangible assets, such as reputation, brand value, strategic position, alliances, knowledge, human capital, play an increasingly important role in shaping the market value of an organization. At the same time, in the literature it is emphasized that the attribute of intangibility translates into an increased risk of destruction or impairment of assets. Thus, the research problem associated with the analysis of organizational reputation risk management as a component of the dynamic capabilities management process should be considered important from the point of view of management science. The study attempts to outline the concept of dynamic capabilities, define the concept of risk and subsequently discuss the relationship between dynamic capabilities and organizational reputation risk management.

Keywords: Dynamic capabilities, reputational risk, organizational reputation risk.

\section{Streszczenie}

Zarządzanie ryzykiem reputacji organizacyjnej jako składowa procesu zarządzania dynamicznymi zdolnościami

W kształtowaniu wartości rynkowej organizacji coraz większy udział mają aktywa niematerialne, takie jak reputacja, wartość marki, pozycja strategiczna, alianse, wiedza, kapitał ludzki. Jednocześnie w literaturze przedmiotu podkreśla się, że owa cecha niematerialności przekłada się na wzrost ryzyka niszczenia czy też utraty wartości aktywów. Tym samym za istotny, z punktu widzenia nauk o zarządzaniu, należy uznać problem badawczy, związany z analizą zarządzania ryzykiem reputacji organizacyjnej jako składową procesu zarządzania dynamicznymi zdolnościami. W opracowaniu podjęto próbę zarysowania koncepcji dy-

17 
namicznych zdolności, zdefiniowania pojęcia ryzyka a następnie podjęcia dyskusji nad relacjami pomiędzy dynamicznymi zdolnościami a zarządzaniem ryzykiem reputacji organizacyjnej.

\section{Stowa}

kluczowe: Dynamiczne zdolności, ryzyko reputacyjne, ryzyko reputacji organizacyjnej.

\section{References}

1. Attitudes of UK Managers to Risk and Uncertainty (2011), Institute of Chartered Accountants of Scotland, Edinburgh.

2. Carey A., Turnbull N. (2000), The Boardroom Imperative on Internal Control, Prentice Hall, London.

3. Dąbrowski T. (2012), Reputacja przedsiębiorstwa [Reputation of a business], Wolters Kluwer, Warsaw.

4. Dowling G. (2011), Creating Corporate Reputations - Identity, Image and Performance, Oxford University Press, Oxford.

5. Eisenhardt K. M., Martin J. A. (2010), Dynamic capabilities: What are they?, Strategic Management Journal, 21 (10-11), pp. 1105-1121.

6. Fombrun Ch. (2010), The value to be found in corporate reputation, Pearson Education, London.

7. Głuszek E. (2014), Zarys modelu dojrzałości zarządzania ryzykiem reputacj [An outline of the reputational risk management maturity model], Management Forum 2, G. Bełz, A. Wierzbic (eds.), UE Wrocław.

8. Mintzberg H., Ahlstrand B., Lampel J. (1999), Strategy Safari: The Complete Guide Through the Wilds of Strategy Management, Prentice Hall, London 1999.

9. Teece D. J. (2008), Dynamic capabilities. In: Lazonick W. (ed.), The international Encyclopedia of Business and Management. Thomas Learning Publishers, London, pp. 1497-1512.

10. Zaman H. (2004), Reputational Risk. How to manage for volume creation, Prentice Hall, New York. 